\title{
PROCESSO ADMINISTRATIVO DISCIPLINAR E SUAS PENALIDADES
}

Giselle Tardioli PEREIRA ${ }^{1}$

Leiner Marchetti PEREIRA ${ }^{2}$

${ }^{1}$ Advogada, graduada pela Faculdade Três Pontas - FATEPS, Pós-Graduanda em Direito Público com Ênfase em Direito Municipal pela Faculdade Três Pontas - FATEPS. E-mail: giselletardioli@ hotmail.com

${ }^{2}$ Advogado, Professor Universitário. Mestre em Direito pela Universidade Vale do Rio Verde - UNINCOR. E-mail: leinermarchetti@hotmail.com

Recebido em: 05/10/2015 - Aprovado em: 14/02/2016 - Disponibilizado em: 30/07/2016

\section{RESUMO:}

O presente trabalho descreve o itinerário pelo qual a Administração Pública utiliza-se para apurar irregularidades funcionais dos seus agentes. Tal abordagem tem por fim demonstrar as formas procedimentais do processo administrativo disciplinar, através de lições trazidas por doutrinadores administrativistas e jurisprudências pátrias. Do estudo realizado evidencia-se que o processo administrativo disciplinar é um dos meios pelo qual se aplica ao servidor penalidades, através do poder administrativo disciplinar, sendo que podem ser revistas pelo Poder Judiciário, todavia somente no que tange ao devido processo legal e sobre o aspecto relacionado à competência.

PALAVRAS-CHAVE: Processo Administrativo Disciplinar. Procedimento. Reintegração

\section{ADMINISTRATIVE DISCIPLINARY PROCESS AND ITS PENALTIES}

\begin{abstract}
:
This paper describes the itinerary by which the Public Administration is used to determine functional irregularities of its agents. This approach is intended to demonstrate the procedural forms of administrative disciplinary process through lessons brought by scholars and jurisprudence administrative homelands. The study shows that the administrative disciplinary process is one of the means by which applies to the server penalties through administrative disciplinary power, and may be reviewed by the judiciary, but only with respect to due process and the aspect related to competence.
\end{abstract}

KEYWORDS: Administrative Disciplinary Process. Penalties. Reinstatement.

\section{INTRODUÇÃO}

O Processo Administrativo Disciplinar é o meio legal utilizado pela Administração para apuração de eventuais infrações funcionais cometidas pelos seus agentes. A didática aqui representada levará em conta a Lei Federal 8.112/90 ou seja, as disposições sobre o processo administrativo disciplinar e sobre a sindicância afeta ao serviço público federal.

Os meios de apuração de irregularidades cometidas pelos agentes públicos no exercício de suas atribuições são a sindicância e o processo administrativo disciplinar - PAD. Ambos os institutos estão disciplinados pelos artigos 143 a 182 da Lei Federal 8.112/90 - Estatuto do Servidor Público Federal.

O presente estudo analisa o processo administrativo disciplinar e o procedimento utilizado para que este seja autuado de forma que não seja possível a anulação da penalidade aplicada ao agente público que 
cometeu infração funcional pelo Poder Judiciário.

Tal análise se justifica pelo fato do processo administrativo disciplinar ter que respeitar um rito, formalidades legais, oportunizando ao agente indiciado direito de defesa a todos os atos, para que assim, respeitando o devido processo legal, a Administração Pública possa eventualmente puni-lo por faltas cometidas no exercício de suas funções ou que tenha relação com as atribuições do cargo que ocupa.

O tema é de suma importância para que seja demonstrado que o processo administrativo disciplinar dá oportunidade à Administração Pública de contar com agentes que bem desempenham suas atribuições, prestando, destarte, serviço público eficiente e de qualidade à população.

Nas palavras de Flávia Cristina Moura de Andrade (2012)

\begin{abstract}
A autoridade que, na sua jurisdição, tiver ciência de irregularidade no serviço público, é obrigada a promover a sua apuração imediata, mediante a instauração de sindicância ou processo administrativo disciplinar. Desta forma, o Processo Administrativo Disciplinar - PAD e a sindicância são os meios de apuração de faltas cometidas pelos agentes públicos no exercício de suas atribuições.
\end{abstract}

Quando a penalidade cabível e adequada à infração funcional for a demissão, cassação de aposentadoria ou disponibilidade, destituição de cargo em comissão, destituição de função comissionada e suspensão superior a 30 (trinta) dias, deverá ser instaurado um processo administrativo disciplinar.

Para as demais penalidades, como a advertência ou suspensão de até 30 (trinta) dias, poderá ser deflagrada a sindicância.

É importante ressaltar que o presente estudo demonstra que, inclusive um servidor público estável poderá perder o cargo que ocupa se cometer infrações funcionais graves que acarretem na pena de demissão, podendo ser reintegrado ao cargo apenas se houver inobservância quando ao procedimento ou excessos praticados pela comissão processante, pela autoridade julgadora ou, ainda, pela autoridade revisora.

Será apresentado o procedimento que deve ser utilizado no processo administrativo disciplinar, as etapas que devem ser observadas para que haja o devido processo legal, elencando as penalidades que possivelmente serão aplicadas ao servidor processado, bem como a competência do Poder Judiciário na apreciação do processo e, ao fim, a possibilidade de reintegração do servidor demitido quando da inobservância aos procedimentos legais.

\section{SINDICÂNCIA}

O procedimento da sindicância é o meio mais célere de apurar irregularidades praticadas pelos agentes públicos. Nos termos 
do art. 145 da Lei 8.112/90, da conclusão de uma sindicância pode ocorrer o seguinte:

a) arquivamento do processo;

b) aplicação direta das penalidades de advertência ou suspensão por até trinta dias; ou

c) instauração de processo administrativo disciplinar se for verificado tratar-se de caso que enseje aplicação de penalidade mais grave. Nessa hipótese, nos termos do art. 154 do Estatuto Federal, os autos da sindicância deverão integrar o processo disciplinar como peça informativa.

Conforme parágrafo único do art. 145, a sindicância tramitará por 30 (trinta) dias, podendo seu prazo conclusivo ser prorrogado, uma única vez.

Haverá circunstâncias investigatórias em que a Administração deflagrará a sindicância sem que haja formalização contra qualquer agente por ausência de acusação contra qualquer agente. Nestas circunstâncias não será obrigatório o devido processo legal com os princípios peculiares do contraditório e ampla defesa, pois não há acusado, tampouco imputação contraditada.

Todas as vezes que o agente público vier a ser penalizado em decorrência de uma sindicância, deverá obrigatoriamente assegurar o devido processo legal, onde o procedimento da sindicância deixa de possuir natureza investigatória e passa a ser caracterizado com um processo administrativo.
Insta salientar que a sindicância não configura uma etapa do processo administrativo disciplinar. No mesmo sentido, nem sempre a sindicância irá preceder ao $\mathrm{PAD}$, eis que o processo administrativo disciplinar pode ser deflagrado diretamente, desde que haja indiciado e a eventual ilicitude funcional praticada definida.

\section{PROCESSO ADMINISTRATIVO DISCIPLINAR}

O estatuto federal traz um conceito de processo administrativo disciplinar elencado no art. 148, "in verbis":

$\begin{array}{lr}\text { Art. 148. O } & \text { processo } \\ \text { disciplinar é o instrumento } \\ \text { destinado a apurar } \\ \text { responsabilidade } \\ \text { servidor por infração } \\ \text { praticada no exercício de } \\ \text { suas atribuições, ou que } \\ \text { tenha relação com as } \\ \text { atribuições do cargo em } \\ \text { que se encontre investido. }\end{array}$

O processo administrativo disciplinar é o instrumento por meio do qual a Administração Pública apura infrações funcionais bem como aplica penalidades aos agentes que a integra.

Verifica-se, destarte, que se trata do instrumento colocado à disposição da Administração Pública para que esta apure a responsabilidade do servidor público que pratica infração no exercício de suas atribuições ou, ainda, que tenha relação com 
as atribuições do cargo que ocupa. Ressalta-se que o processo administrativo disciplinar não tem por finalidade apenas apurar a responsabilidade do servidor que supostamente tenha praticado alguma infração funcional, mas também de oferecer ao servidor o direito de provar sua inocência, através do direito ao contraditório e à ampla defesa.

No que tange ao procedimento, Hely Lopes Meirelles (2009, p. 697) e Maria Sylvia Zanela Di Pietro (2006, p. 614), apontam que este se desenvolve nas seguintes fases: “instauração, instrução, defesa, relatório e decisão".

As referidas fases do processo contam com certas formalidades sem as quais $\mathrm{o}$ procedimento deixa de atender aos requisitos legais, podendo gerar eventuais nulidades.

A seguir serão tratadas de forma pormenorizada as etapas do procedimento, para que haja o total respeito ao princípio constitucional do devido processo administrativo disciplinar ${ }^{1}$. Conforme já mencionado, o Processo Administrativo Disciplinar está instrumentalizado em etapas ou fases, o que será detidamente analisado abaixo.

\footnotetext{
${ }^{1}$ Art. $5^{\circ}(\ldots)$

LIV - ninguém será privado da liberdade ou de seus bens sem o devido processo legal;
}

\subsection{Instauração}

A instauração do PAD ocorre com a publicação da portaria de designação da comissão encarregada de proceder com os trabalhos investigativos, devendo, ao final, apresentar um relatório conclusivo sobre a procedência ou não das acusações levantadas, o qual será remetido e acatado pela autoridade julgadora, salvo se contrário às provas dos autos.

A autoridade competente tem a obrigação de, tendo ciência de qualquer irregularidade cometida no serviço público, determinar a instauração do processo administrativo disciplinar. As irregularidades para que sejam apuradas devem estar sob a forma escrita, com a identificação e endereço do denunciante, com identificação da autenticidade da denúncia. Se $\mathrm{o}$ fato denunciado não configurar ilícito funcional e/ou penal, a denúncia será arquivada, por falta de objeto, nos exatos termos do parágrafo único do art. 144 da Lei $\mathrm{n}^{\circ}$ $8.112 / 90$.

Destarte, a instauração propriamente dita do processo nada mais é que a descrição dos supostos fatos cometidos pelo agente e a indicação do dispositivo estatutário por ele violado. Para o professor Hely Lopes Meirelles (2009, p. 697) “o essencial é que a peça inicial descreva os fatos com suficiente especificidade, de modo a delimitar o objeto da controvérsia e a permitir a plenitude da defesa". 
O processo administrativo disciplinar será conduzido por uma comissão composta de três agentes públicos estáveis que deverá ser designada pela autoridade competente, indicando aquele que presidirá referida comissão $\mathrm{O}$ presidente da comissão deverá ser ocupante de cargo efetivo superior ou de mesmo nível, ou ter escolaridade igual ou superior ao do acusado, conforme denota-se no art. 149.

Depois de recebida a peça inaugural, em atendimento ao princípio da oficialidade ${ }^{2}$, inicia-se efetivamente o processo administrativo disciplinar, momento em que a comissão processante é obrigada a comunicar ao servidor acusado que será submetido a um processo, podendo, ainda, caso entenda pertinente, pedir o seu afastamento das atividades.

Conforme disposição contida no art. 152 do Estatuto Federal, o PAD deverá ser concluído em até 60 (sessenta) dias, contados da data de publicação do ato que constituir a comissão, admitida sua prorrogação por igual prazo, a critério da autoridade instauradora, quando as circunstâncias assim o exigirem.

\subsubsection{Afastamento Temporário}

O afastamento preventivo do agente público está previsto no art. 147 da norma estatuária, veja-se:

${ }^{2} \mathrm{O}$ princípio da oficialidade caracteriza-se pelo dever da Administração em impulsionar o procedimento de forma automática, sem prejuízo da atuação dos interessados.
Art. 147. Como medida cautelar e a fim de que o servidor não venha a influir na apuração da irregularidade, a autoridade instauradora do processo disciplinar poderá determinar o seu afastamento do exercício do cargo, pelo prazo de até 60 (sessenta) dias, sem prejuízo da remuneração. Parágrafo único. $\mathrm{O}$ afastamento poderá ser prorrogado por igual prazo, findo o qual cessarão os seus efeitos, ainda que não concluído o processo.

O afastamento cautelar do agente público é ato discricionário da autoridade instauradora do PAD, no intuito de evitar que o investigado venha a influir no trâmite do processo, prejudicando seu andamento.

Referido afastamento não se trata de penalidade, mas de medida acautelatória visando garantir a lisura do processo. $\mathrm{O}$ agente afastado não sofre prejuízo em sua remuneração durante o período do afastamento. $\mathrm{O}$ período máximo de afastamento é de 60 (sessenta) dias, prorrogado por igual período, findo o qual cessarão seus efeitos, ainda que não concluído o processo.

\subsection{Inquérito Administrativo}

A fase do PAD denominada inquérito administrativo compõem de três subfases ou etapas: instrução, defesa e relatório. 


\subsubsection{Instrução}

A fase de instrução do processo administrativo disciplinar consiste na elucidação dos fatos narrados na peça inicial bem como na produção de provas. As providências instrutórias cabem à autoridade competente ou à comissão processante.

Conforme ensinamento de Marcelo Alexandrino (2007):

\begin{abstract}
A instrução é a principal fase investigatória do PAD. É durante a instrução que a comissão procurará levantar o maior número possível de fatos, evidências, depoimentos, enfim, todos os elementos capazes de confirmar ou refutar as acusações de pesam sobre o servidor.
\end{abstract}

Na hipótese de ter havido sindicância prévia, sendo que tal fato não é obrigatório, os autos integrarão o PAD como peça informativa, sendo que a decisão da sindicância não vincula a comissão do PAD. Se o relatório da sindicância indicar elementos suficientes configuradores de ilícito penal, os autos deverão ser encaminhados ao Ministério Público, para análise de instauração de processo criminal.

Nos termos do art. 155, na fase do inquérito, a comissão promoverá a tomada de depoimentos, acareações, investigações e diligências cabíveis, objetivando a coleta de prova, recorrendo, quando necessário, a técnicos e peritos, de modo a permitir a completa elucidação dos fatos. Se o fato relacionado depender de conhecimento técnico especializado, conforme art. $156, \S 2^{\circ}$, poderá haver pedido de perícia pelo presidente da comissão.

Nesta fase poderão ser produzidas provas documentais, testemunhais, periciais, depoimento pessoal da parte acusada, dentre outros meios de provas admitidos em Direito. Todavia, questão de grande relevância é a observância do disposto no artigo 30, da Lei Federal $n^{\circ} 9.784 / 99^{3}$, que prevê a proibição da utilização de provas obtidas por meio ilícito no processo administrativo, outrossim, é garantido ao acusado a faculdade de acompanhar todo o procedimento de produção de provas, podendo, caso queira, fazer se representar por um advogado.

Segundo Maria Sylvia Zanella Di Pietro, a comissão processante:

toma iniciativa para
levantamento das provas,
podendo realizar ou
determinar todas as
diligências que julgue
necessárias a essa
finalidade. O princípio do
contraditório exige, em
contrapartida, que a
comissão dê ao indiciado
oportunidade
acompanhar a instrução"
(DI PIETRO, 2006, p.
614).

$\mathrm{O}$ agente público investigado tem o direito de acompanhar pessoalmente ou por intermédio de procurador (que não

\footnotetext{
${ }^{3}$ Lei $9.784 / 99$ que "Regula o processo administrativo no âmbito da Administração Pública Federal"
} 
necessariamente precisa ser advogado) todos os atos do PAD, mesmo que esteja temporariamente afastado, tudo para que não ocorra o cerceamento de defesa, hipótese de nulidade da instrução (art.156).

A comissão poderá ouvir testemunhas arroladas pelo acusado, por ela própria ou por terceiros. O testemunho deve ser prestado oralmente e reduzido a termo, sendo cada testemunha ouvida separadamente, e, havendo contradição, poderá ser marcada acareação.

Após a coleta de provas e a inquirição de testemunhas, será ouvido o acusado, com as mesmas regras atinentes às testemunhas.

Concluído todos estes procedimentos, a comissão, de posse de uma série de elementos de prova, decidirá, com base nesses elementos, se o servidor deverá ou não ser indiciado. Se a comissão entender que não há provas contra o acusado, o processo será arquivado. Se entender o contrário, a comissão formulará a indiciação do servidor, devendo constar os fatos imputados ao indiciado e as provas produzidas. Após a indiciação deverá ser providenciada a citação do indiciado para apresentação de defesa, no prazo de 10 (dez) dias, assegurando vista dos autos, conforme disposição contida no art. 161 da Lei $n^{\circ} 8.112 / 90$.

Denota-se que no PAD, a instrução antecede a apresentação de defesa, eis que esta vem somente após a indiciação. A citação encerra a fase de instrução, passando a fase seguinte que é a fase da defesa.

\subsubsection{Defesa}

Prevista no artigo $5^{\circ}$, inciso LV da Lei Maior, a defesa é garantida constitucionalmente a todo acusado em processo judicial ou administrativo, compreendendo a ciência da acusação, por meio de citação pessoal, vista dos autos na repartição, oferecimento de defesa (contestação) e provas, inquirição e reperguntas às testemunhas e observância do devido processo legal, assegurados os direitos ao contraditório e à ampla defesa.

Cumpre ressaltar que a defesa do acusado poderá ser redigida por ele próprio ou por advogado por ele constituído, tal posição é pacífica na jurisprudência pátria, tendo sido o assunto sumulado pelo Supremo Tribunal Federal - STF, através da Súmula Vinculante 5, nos seguintes termos: "A falta de defesa técnica por advogado no processo administrativo disciplinar não ofende a Constituição".

Conforme as regras oriundas do processo civil brasileiro, na hipótese de o réu ter sido regularmente citado e não apresentar sua defesa no prazo consignado na legislação processual, será considerado revel, sendo que os efeitos da revelia traduzem como verdadeiras as alegações invocadas contra ele, ou seja, a revelia equivale a uma confissão, eis que no processo civil vigora a verdade formal, ou seja aquela revelada nos autos.

No PAD, na hipótese de o indiciado não apresentar sua defesa escrita no prazo 
consignado na lei, também será declarada a revelia, toda devido a verdade material característicos do PAD, não surge nenhuma presunção legal contra o agente indiciado e, para defendê-lo, será nomeado um defensor dativo, que deverá ser ocupante de cargo efetivo superior ou de mesmo nível, ou ter nível de escolaridade igual ou superior ao do indiciado. Desta forma pode-se afirmar que sempre haverá uma defesa escrita no PAD, mesmo que não seja feita pelo indiciado ou seu procurador. Salienta-se que a revelia não possui efeito de confissão.

Insta lembrar que o processo administrativo em que não foi oportunizado ao acusado a ampla defesa ou tenha sido esta cerceada, trata-se de processo nulo, não produzido nenhum efeito jurídico.

No entanto, esclarece-se que isso não impede o indeferimento de provas impertinentes ou requeridas com caráter protelatório ou tumultuário pela autoridade que preside o processo, devendo tal indeferimento ocorrer com a devida justificação para não ensejar cerceamento de defesa do acusado.

\subsubsection{Relatório}

Encerrada a fase da defesa, inicia-se o relatório que compreende a síntese do processo elaborada pela comissão processante depois de apreciadas as provas, analisados os fatos apurados e enquadrados no direito debatido. O relatório nada mais é que uma conclusão do que se verificou no curso do processo que será encaminhada para autoridade competente para que essa profira seu julgamento em relação aos fatos apurados.

Sábias são as palavras do saudoso Hely Lopes Meirelles, sobre o tema, veja-se:

$\begin{aligned} & \text { Concluída a instrução, a } \\ & \text { comissão processante }\end{aligned}$
deverá relatar o apurado e
opinar pela absolvição ou
punição do acusado,
indicando, neste caso, os
dispositivos infringidos,
podendo divergir da
acusação inicial, sugerir a
instauração de outros
processos e apontar
providências de
complementares
interesse da
Administração, desde que
o faça motivadamente
(MEIRELLES, 2009, p.
704).

Aduz o art. 165 da Lei no 8.112/90:

Art. 165. Apreciada a defesa, a comissão elaborará relatório minucioso, onde resumirá as peças principais dos autos e mencionará as provas em que se baseou para formar a sua convicção. $\S 1^{\circ} \mathrm{O}$ relatório será sempre conclusivo quanto à inocência ou à responsabilidade do servidor.

$\S 2^{\circ} \quad$ Reconhecida a responsabilidade do servidor, a comissão indicará o dispositivo legal ou regulamentar transgredido, bem como as circunstâncias agravantes ou atenuantes.

Conforme dispositivo acima colacionado, o relatório deverá conter um resumo dos autos, mencionando as provas que 
a comissão levou em consideração para basear sua convicção.

O relatório deve concluir por algo, ou seja, a comissão deve opinar pela inocência do indiciado ou sua responsabilidade. Se opinar pela responsabilidade, o relatório deverá consignar os dispositivos legais que foram transgredidos, bem como as circunstâncias agravantes e atenuantes.

As circunstâncias agravantes ou atenuantes são levadas em consideração quando da graduação da penalidade, conforme disposto no art. 128 da norma estatutária.

A peça poderá ser opinativa, todavia, a sugestão que por ventura estiver consubstanciada no relatório não vincula a decisão da Administração, possuindo esta liberdade para divergir das conclusões e sugestões da comissão, desde que sua decisão seja fundamentada em elementos constantes dos autos ou na insuficiência de provas para aplicação de penalidade. Depara-se, então, que o relatório possui caráter meramente informativo.

Concluído o relatório, encerram-se os trabalhos da comissão, sendo o PAD remetido à autoridade julgadora que determinou sua instauração, para julgamento, conforme denota-se a disposição do art. 166.

\subsection{Julgamento}

O julgamento do processo
administrativo disciplinar deve respeitar,
primeiramente as regras de competência,

relativas à aplicação das supostas penalidades, conforme regras estatuídas no art. 141 do Estatuto Federal, veja-se:

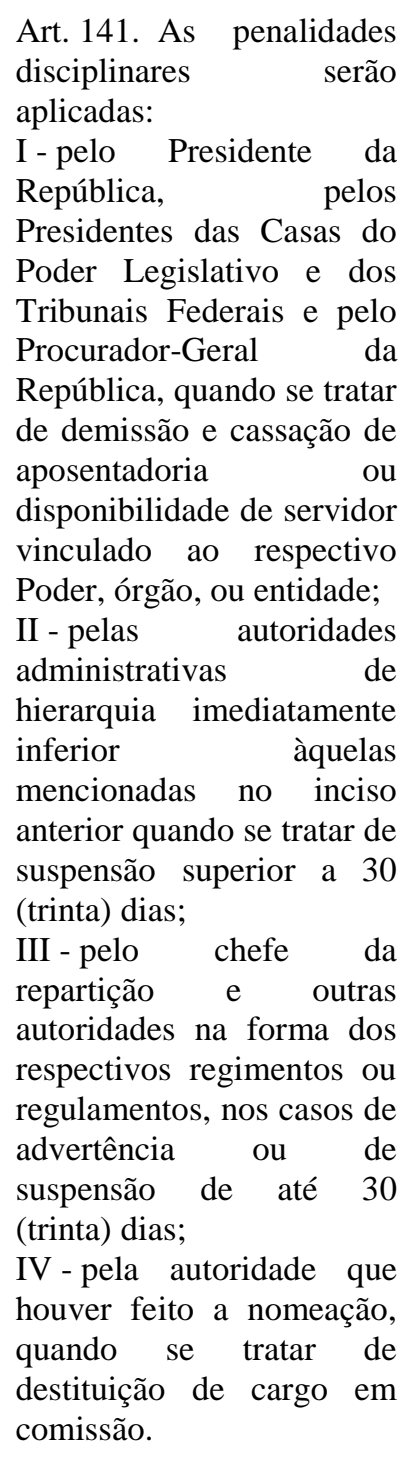

Conforme dispõe o art. 167 da Lei Federal $\mathrm{n}^{\circ} 8.112 / 90$, a autoridade julgadora deverá proferir sua decisão em 20 (vinte) dias contados do recebimento do processo. Nos termos dos ensinamentos de Vicente Paulo (2007):
(...) esse prazo não é peremptório, vale dizer, caso não seja cumprido, não há nulidade do 
processo. A consequência que pode decorrer da demora no julgamento é a prescrição da punição quando a infração administrativa for também tipificada como crime, pois, nesse caso, a prescrição penal acarreta também a prescrição administrativa.

A fase do julgamento que nada mais é que a decisão da lavra da autoridade julgadora acerca do objeto constante do processo; essa decisão acolherá ou não o relatório apresentado pela comissão que dirigiu os trabalhos. Decidindo de forma diversa da sugerida, a autoridade fundamentará a decisão em provas constantes dos autos, com base na acusação e na defesa.

Não se admite, porém, o julgamento sem fundamentação, ainda que feita de forma sucinta, pois a punição aplicada sem justificativa em elementos é nula, vez que deixa de ser ato disciplinar legítimo e passa a ser ato arbitrário, portanto, ilegal e passível de invalidação.

Conforme mencionado, não há vinculação da autoridade julgadora aos termos do relatório da comissão processante, todavia, caso o julgamento seja realizado em dissonância com aquilo que restou relatado pela comissão, a autoridade deverá motivar a sua decisão, podendo agravar ou abrandar a penalidade proposta ou isentar o servidor de penalidade, conforme art. 168 da norma estatutária.
Ponto que merece destaque acerca dos julgamentos proferidos em processo administrativo é a utilização de imputações não constantes da portaria de instauração, aplicando-se ao servidor, de forma indefensável, penalidade aplicável à conduta diversa da por ele praticada e descrita na peça inaugural.

O Supremo Tribunal Federal, nos autos de MS 22939-CE, decidiu pela nulidade de punição por infração diversa daquela pela qual o servidor foi indiciado:

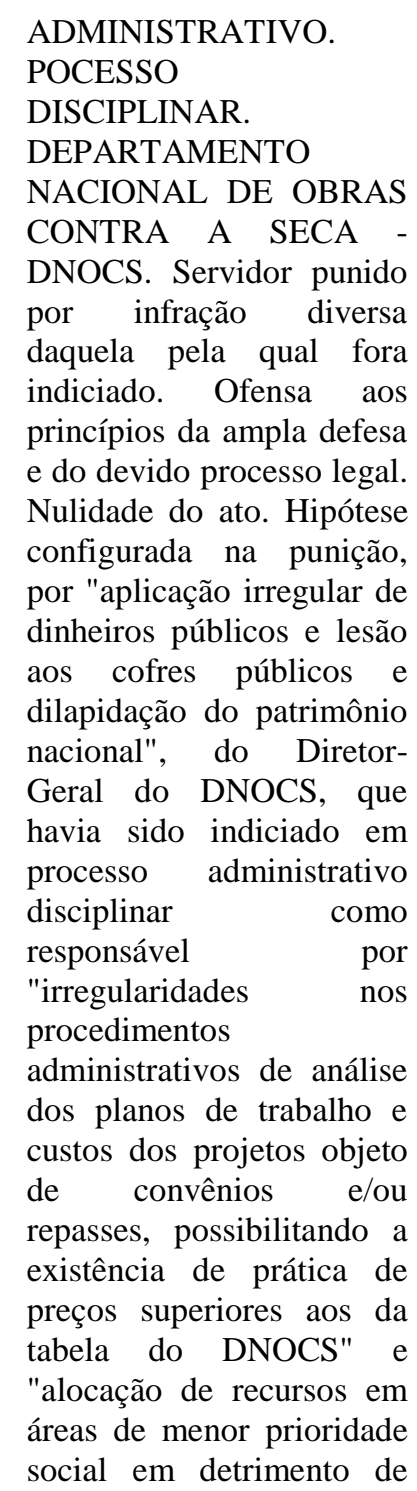


outras obras que, por falta de recursos orçamentários, não foram concluídas", sem houvesse sido chamado a defender-se sobre os novos fatos. ${ }^{4}$

Verificada a ocorrência de vício insanável, a autoridade que determinou a instauração do processo ou outra de hierarquia superior declarará a sua nulidade, total ou parcial, e ordenará, no mesmo ato, a constituição de outra comissão para instauração de novo processo, conforme redação contida no art. 169 da Lei Federal no 8.112/90.

O que resta claro com estas considerações é que a autoridade julgadora, quando proferir a decisão, deverá embasar-se em provas constantes no processo, vinculadas aos fatos e que tenham oportunizado defesa para o indiciado, não podendo jamais inovar nos fatos durante o trâmite processual, sob pena de contaminar o devido processo legal, o contraditório e a ampla defesa, princípios previstos no artigo $5^{\circ}$, incisos LIV e LV, da Constituição da República.

\subsubsection{Penalidades}

Ao final do julgamento do processo administrativo, não havendo arquivamento dos autos, ou seja, absolvição do indiciado, serão aplicadas penalidades, considerada a

\footnotetext{
${ }^{4}$ (Rel. Min. Ilmar Galvão, j. 17.2.2000, DJU 6.4.2001, p. 70). Disponível em: < http://www.jusbrasil.com.br/jurisprudencia/busca?q=cit am\%3AMS+22939\&s=jurisprudencia\&l=7dias Acesso em 22 de janeiro de 2016
}

natureza e a gravidade da infração cometida, os danos que dela provierem para o serviço público, as circunstâncias agravantes ou atenuantes e os antecedentes funcionais do servidor processado.

As penalidades estão disciplinadas nos estatutos dos servidores dos entes federais, estaduais e municipais e, na maioria das vezes, os dois últimos repetem o descrito no Estatuto do Servidor Público Federal, Lei $n^{\circ}$ 8.112/90, que prevê as seguintes sanções:

\author{
Art. 127. São penalidades \\ disciplinares: \\ I - advertência; \\ II - suspensão; \\ III - demissão; \\ IV - cassação de \\ aposentadoria ou \\ disponibilidade; \\ V - destituição de cargo \\ em comissão; \\ VI - destituição de função \\ comissionada.
}

Os estatutos dos servidores tipificam cada conduta infratora e, de acordo com a gravidade e prejuízo ao serviço público do ato do servidor são aplicadas as penalidades. A advertência é sempre a penalidade mais branda, devendo ser aplicada de forma escrita. A suspensão será aplicada nos casos de reincidência da pena de advertência e demais casos que preveja sua aplicação direta. A demissão será aplicada nos casos em que o desrespeito a normas funcionais forem bastante graves e causem prejuízos ao serviço público, trata-se, pois, da pena mais severa aplicada ao servidor, capaz, inclusive, de excluir dos quadros da Administração o 
servidor que já tenha adquirido a estabilidade.

Tão severa quanto à demissão é a penalidade de cassação de aposentadoria ou disponibilidade. Já as penas de destituição de cargo em comissão e função comissionada, muitas vezes não são aplicadas mediante instauração de processo administrativo disciplinar, vez que se existe dúvida quanto à conduta do ocupante de cargo comissionado ou função de confiança, a autoridade competente poderá simplesmente exonerá-lo, tendo em vista que a nomeação e exoneração dos ocupantes dos referidos cargos dependem exclusivamente da confiança da autoridade, não havendo mais confiança no servidor, tão logo podem ser exonerados livremente, não havendo, portanto, necessidade de um devido processo legal.

\section{RITO SUMÁRIO}

Para as hipóteses de acumulação ilícita de cargos públicos, de abandono de cargo ou de inassiduidade habitual, fruto de alterações promovidas pela Lei $\mathrm{n}^{\circ}$ 9.527/97, o Estatuto Federal foi modificado para prever um rito especial de procedimento para referidas hipóteses no processo administrativo disciplinar,

Neste sentido é a redação do art. 133 e do art. 140, ambos da Lei Federal no 8.112/90, "in verbis": cargos, empregos ou funções públicas, a autoridade a que se refere o art. 143 notificará o servidor, por intermédio de sua chefia imediata, para apresentar opção no prazo improrrogável de dez dias, contados da data da ciência e, na hipótese de omissão, adotará procedimento sumário para a sua apuração e regularização imediata, cujo processo administrativo disciplinar se desenvolverá nas seguintes fases:

I - instauração, com a publicação do ato que constituir a comissão, a ser composta por dois servidores estáveis, e simultaneamente indicar a autoria e a materialidade da transgressão objeto da apuração;

II - instrução sumária, que compreende indiciação, defesa e relatório;

III - julgamento.

$\S 1^{\mathrm{o}} \mathrm{A}$ indicação da autoria de que trata o inciso I darse-á pelo nome e matrícula do servidor, e a materialidade pela descrição dos cargos, empregos ou funções públicas em situação de acumulação ilegal, dos órgãos ou entidades de vinculação, das datas de ingresso, do horário de trabalho e do correspondente regime jurídico.

$\S 2^{\mathrm{o}} \mathrm{A}$ comissão lavrará, até três dias após a publicação do ato que a constituiu, termo de indiciação em que serão transcritas as informações de que trata o parágrafo anterior, bem como promoverá a citação pessoal do servidor indiciado, ou por intermédio de sua chefia imediata, para, no prazo de cinco dias, apresentar defesa escrita, assegurando-se-lhe vista 
do processo na repartição, observado o disposto nos arts. 163 e 164.

$\S 3^{\circ}$ Apresentada a defesa, a comissão elaborará relatório conclusivo quanto à inocência ou à responsabilidade do servidor, em que resumirá as peças principais dos autos, opinará sobre a licitude da acumulação em exame, indicará o respectivo dispositivo legal e remeterá o processo à autoridade instauradora, para julgamento.

$\S 4^{\circ}$ No prazo de cinco dias, contados do recebimento do processo, a autoridade julgadora proferirá a sua decisão, aplicando-se, quando for o caso, o disposto no $\S 3^{-}$do art. 167.

$\S 5^{\mathrm{o}} \mathrm{A}$ opção pelo servidor até o último dia de prazo para defesa configurará sua boa-fé, hipótese em que se converterá

automaticamente em pedido de exoneração do outro cargo.

$\S 6^{\circ}$ Caracterizada a acumulação ilegal e provada a má-fé, aplicarse-á a pena de demissão, destituição ou cassação de aposentadoria ou disponibilidade em relação aos cargos, empregos ou funções públicas em regime de acumulação ilegal, hipótese em que os órgãos ou entidades de vinculação serão comunicados.

$\S 7^{\circ} \mathrm{O}$ prazo para a conclusão do processo administrativo disciplinar submetido ao rito sumário não excederá trinta dias, contados da data de publicação do ato que constituir a comissão, admitida a sua prorrogação por até quinze dias, quando as circunstâncias o exigirem.

$\S 8^{\circ} \mathrm{O} \quad$ procedimento sumário rege-se pelas disposições deste artigo, observando-se, no que lhe for aplicável,

subsidiariamente, as disposições dos Títulos IV e V desta Lei.

Art. 140. Na apuração de abandono de cargo ou inassiduidade habitual, também será adotado o procedimento sumário a que se refere o art. 133, observando-se especialmente que:

I - a indicação da materialidade dar-se-á:

a) na hipótese de abandono de cargo, pela indicação precisa do período de ausência intencional do servidor ao serviço superior a trinta dias;

b) no caso de inassiduidade habitual, pela indicação dos dias de falta ao serviço sem causa justificada, por período igual ou superior a sessenta dias interpoladamente, durante o período de doze meses; II - após a apresentação da defesa a comissão elaborarár relatório conclusivo quanto à inocência ou à responsabilidade do servidor, em que resumirá as peças principais dos autos, indicará o respectivo dispositivo legal, opinará, na hipótese de abandono de cargo, sobre a intencionalidade da ausência ao serviço superior a trinta dias e remeterá o processo à autoridade instauradora para julgamento.

\section{O processo administrativo disciplinar}

submetido ao rito sumário previsto nos artigos 133 e 140 do Estatuto Federal segue subsidiariamente, as disposições do processo administrativo disciplinar do rito ordinário. 


\section{REVISÃO DO PROCESSO}

De acordo com as disposições contidas acerca do processo administrativo disciplinar, o referido processo corre em instância única, não havendo instância superior na qual o agente processado possa recorrer automaticamente. Para chegar a tal conclusão basta analisar que algumas penalidades, tal qual a demissão é aplicada diretamente pelo Chefe do Poder que, no caso do Executivo Federal, é próprio Presidente da República. Desta forma, a quem caberia o recurso, tendo em vista que, hierarquicamente não há autoridade no Executivo Federal acima da Presidência da República?

A revisão do processo somente é cabível quando restar comprovada a existência de fatos novos ou circunstâncias suscetíveis de justificar a inocência do punido ou, ainda, a inadequação da penalidade aplicada, conforme disposição do art. 174 da Lei Federal $n^{\circ} 8.112 / 90$, sendo que o ônus da prova nesse caso é invertido, ou seja, cabe ao recorrente provar os fatos alegados.

Como a revisão do processo não se trata de recurso automático, a mera alegação de injustiça da penalidade não constitui motivo para análise do pedido de revisão, eis que tal espécie sempre exige elementos novos, ainda não apreciados no processo originário (art. 176).

O juízo de admissibilidade da revisão do processo cabe ao Ministro de Estado ou autoridade equivalente nos outros entes da federação, sendo que se for deferida a revisão, será constituída uma comissão de revisão, observadas as mesmas regras da comissão processante, a qual terá o prazo de 60 (sessenta) dias, improrrogáveis para conclusão dos trabalhos.

Cabe a autoridade que aplicou a penalidade julgar, no prazo de 20 (vinte) dias não peremptórios, o pedido de revisão do processo.

Salienta-se que da revisão não pode acarretar agravamento da penalidade, não sendo admitido a reformatio in pejus.

\section{APRECIAÇÃO PELO PODER JUDICIÁRIO}

É permitido ao Judiciário o exame apenas no que tange à competência e a análise procedimental, ou seja, se houve o atendimento ao devido processo legal.

Essa verificação importa conhecer os motivos da punição e saber se foram atendidas as formalidades procedimentais essenciais. Por formalidades procedimentais essenciais, entende-se o respeito à oportunidade de defesa ao servidor acusado e os limites da competência funcional dos membros da comissão processante e da autoridade julgadora.

De forma louvável como de costume, o saudoso Hely Lopes Meirelles expõe como o Poder Judiciário pode examinar um processo administrativo disciplinar sem interferir na discricionariedade da 
Administração pública, veja o brilhantismo da explicação: $\begin{array}{ll}\text { Permitido é ao Poder } \\ \text { Judiciário } & \text { examinar o } \\ \text { processo administrativo }\end{array}$ disciplinar para verificar se a sanção imposta é legítima e se a apuração da infração atendeu ao devido procedimento legal. Essa verificação importa conhecer os motivos da punição e se saber se foram atendidas as formalidades

procedimentais essenciais, notadamente oportunidade de defesa ao acusado e contenção da comissão processante e da autoridade julgadora nos limites de sua competência funcional, isto sem tolher o discricionarismo da Administração quanto à escolha da pena aplicável dentre as consignadas na lei ou regulamento do serviço, à graduação quantitativa da sanção e à conveniência ou oportunidade de sua imposição. O que se nega ao Judiciário é o poder de substituir ou modificar penalidade disciplinar a pretexto de fazer justiça, pois, ou a punição é legal, e deve ser confirmada, ou é ilegal, e há que ser anulada; inadmissível é a substituição da discricionariedade legítima do administrador por arbítrio ilegítimo do juiz. (MEIRELLES, 2009, p. 704 e 705)

Desta forma, resta evidente que o Poder Judiciário ao apreciar um processo administrativo disciplinar conduzido pela Administração Pública deve abster-se às formalidades procedimentais essenciais e nunca adentrar ao mérito do ato administrativo, sob pena de tornar-se arbitrariedade.

\section{REINTEGRAÇÃO DO SERVIDOR DEMITIDO}

Conforme já exposto, o agente público poderá, dentre outras penalidades, ser demitido do serviço público por meio de processo administrativo disciplinar em que lhe seja assegurado o direito ao contraditório e à ampla defesa desde que tenha praticado alguma das infrações disciplinares descritas no artigo 132, da Lei Federal no 8.112/90 Estatuto do Servidor Público Federal, assim como em estatutos estaduais e municipais.

No entanto, a Constituição da República prevê, no $\S 2^{\circ}$, do artigo 41 , que o ato demissional praticado pela autoridade competente para julgar o processo administrativo disciplinar poderá ser invalidado por sentença judicial, reintegrando o servidor demitido ao cargo por ele antes ocupado.

Esta reintegração do servidor ao mesmo cargo de que fora demitido, acontece com o pagamento integral dos vencimentos e vantagens do tempo em que esteve afastado desde que a demissão por ele sofrida tenha sido ilegal, ou seja, sem observância às formalidades legais.

CONSTITUCIONAL E ADMINISTRATIVO. SERVIDOR PÚBLICO. 


$\begin{array}{lr}\text { EXONERAÇÃO } & \\ \text { ILEGAL. } & \\ \text { REINTEGRAÇÃO } & \text { AO } \\ \text { CARGO. PAGAMENTO } \\ \text { INTEGRAL } & \text { DOS } \\ \text { VENCIMENTOS } & \text { E } \\ \text { VANTAGENS } & \\ \text { REFERENTES } & \text { AO } \\ \text { PERÍODO } & \text { DO } \\ \text { AFASTAMENTO } & \\ \text { INDEVIDO. } & \text { APELO } \\ \text { CONHECIDO } & \text { E } \\ \text { PROVIDO. } & \\ \text { l. }\end{array}$

1. O reconhecimento da ilegalidade da exoneração implica no pagamento integral dos vencimentos e vantagens ao servidor público correspondente ao período do Indevido afastamento do cargo. ${ }^{5}$

Ainda que a Constituição da República (art. $41, \S 2^{\circ}$ ) disponha que a referida reintegração se dará apenas por decisão judicial, sabe-se que a Administração Pública possui competência para revogar seus atos quando eivados de vício, assim, resta claro que a reintegração do servidor demitido ilegalmente pode ocorrer por decisão tanto judicial quanto administrativa.

Destarte, para que não ocorra a reintegração do servidor demitido, é necessário que o Poder Público, quando da aplicação da pena, aja em observância aos princípios do devido processo legal, assegurando, durante toda a fase instrutória do processo administrativo o direito ao

${ }^{5}$ Apelação Cível AC 77005 RN 2011.007700-5

(TJRN). Disponível em:

<http://www.jusbrasil.com.br/jurisprudencia/busca?q= PERCEP $\%$ C3\% 87\%C3\%830+DAS+VANTAGENS+ REFERENTES+AO+PER\%C3\%8DODO+DE+AFAS TAMENTO\&s=jurisprudencia\&l=365dias $>$ Acesso em 22 de janeiro de 2016 contraditório e à ampla defesa ao servidor acusado de ter praticado qualquer infração disciplinar passível de demissão.

Faz-se necessário salientar que por garantia de defesa entende-se não apenas a observância do rito adequado, mas também a cientificação do processo ao acusado, a oportunidade para oferecer contestação à denúncia, produzir provas, acompanhar a instrução bem como interpor os recursos cabíveis.

Não cumpridas as exigências legais, sendo reconhecida a ilegalidade do ato demissional, deve ser o servidor reintegrado ao cargo por ele antes ocupado, percebendo o recebimento integral de vencimentos e vantagens do tempo em que esteve injustamente afastado, este é o posicionamento do Tribunal de Justiça de Minas Gerais:

CONSTITUCIONAL/AD
MINISTRATIVO -
SERVIDORPÚBLICO
REINTEGRAÇÃO
EFEITOS "EX TUNC" -
DESNECESSIDADE DE
"NOVA POSSE" -
IMPOSSIBILIDADE DE
ACUMULAÇÃO DE
DOIS CARGOS
PÚBLICOS DO
INCOMPATIBILIDADE
DE HORARIOS
ABANDONO
CARGO - DEMISSÃO -
REGULARIDADE. A
reintegraçãodoservidorpúb
lico ao cargo em que fora
ilegalmente demitido
retroage à data do ato
ilegal, revalidando os atos
administrativos praticados,
anteriormente


sendo desnecessária nova nomeação e posse ao mesmo. Estando o servidor público em exercício no cargo em que foi reintegrado, correto $\mathrm{o}$ procedimento

administrativo que culminou em sua demissão, em virtude do abandono do cargo por mais de 30 dias. $^{6}$

A doutrina denomina esta reinvestidura do servidor ao cargo por ele ocupado depois de reconhecida a ilegalidade da decisão que o demitiu de reintegração. Trata-se de previsão encontrada no art. 28 da Lei Federal $n^{\circ} 8.112$, o qual segue transcrito:

Art. 28. A reintegração é a reinvestidura do servidor estável no cargo anteriormente ocupado, ou no cargo resultante de sua transformação, quando invalidada a sua demissão por decisão administrativa ou judicial, com ressarcimento de todas as vantagens.

$\S 1^{\circ} \mathrm{Na}$ hipótese de o cargo ter sido extinto, o servidor ficará em disponibilidade, observado o disposto nos arts. 30 e 31 .

$\S \quad 2^{\circ} \quad$ Encontrando-se provido o cargo, o seu eventual ocupante será reconduzido ao cargo de origem, sem direito à indenização ou aproveitado em outro cargo, ou, ainda, posto em disponibilidade.

${ }^{6}$ Apelação Cível no 1.0028.02.001868-6/001 -

Comarca de Andrelândia. Disponível em:

<http://www.jurisway.org.br/v2/pergunta.asp?idmodel o=9896> Acesso em 22 de janeiro de 2016
Oportunamente, cabe enfatizar a diferença dos institutos da reintegração e da recondução, que ocorre se a pessoa que ocupou o cargo vago pela demissão ilegal também é servidor estável, devendo ser reconduzido ao cargo de origem, sem direito à indenização, conforme dispõe o $\S 2^{\circ}$, do art. 41 da CR c/c art. 29, inciso II, da Lei $8.112 / 90)^{7}$.

Vale destacar ainda que o Poder Judiciário poderá modificar decisão administrativa apenas quanto às questões legais, ou seja, quando os atos forem praticados com inobservância das formalidades previstas na legislação vigente. Nesse sentido veja a posição do Tribunal de Justiça de Minas Gerais:

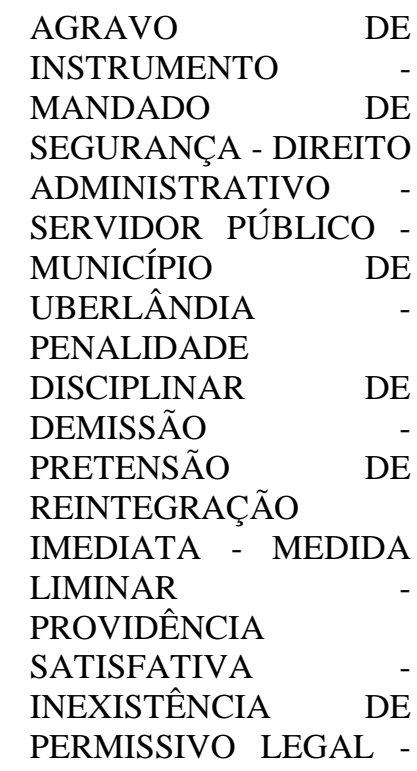

\footnotetext{
${ }^{7}$ Art. 29. Recondução é o retorno do servidor estável ao cargo anteriormente ocupado e decorrerá de:

I - inabilitação em estágio probatório relativo a outro cargo;

II - reintegração do anterior ocupante.

Parágrafo único. Encontrando-se provido o cargo de origem, o servidor será aproveitado em outro, observado o disposto no art. 30.
} 
ART. $7^{\circ}$, INCISO III, DA
LEI N. 12.016/09 -
FUMUS BONI IURIS -
NÃO DEMONSTRAÇÃO
- PROCEDIMENTO
ADMINISTRATIVO
REGULAR
OBSERVÂNCIA AOS
PRINCÍPIOS DO DO DO
CONTRADITORIO E DA
AMPLA DEFESA -
ANÁLISE DO
CONJUNTO
PROBATÓRIO
DISCRICIONARIEDADE
DA ADMINISTRAÇÃO -
RISCO DE INEFICÁCIA
DO PROVIMENTO
FINAL - AUSENCIA -
RECURSO
PROVIDO.

1. A Lei do Mandado de Segurança (Lei n. 12.016/09), em seu art. $7^{\circ}$, inciso III, possibilita a concessão de medida liminar para a suspensão do ato que deu motivo ao pedido, e não para se impor, à autoridade impetrada, a prática de determinada conduta como a imediata reintegração de servidor no cargo do qual foi demitido -, sob pena de a pretensão liminar postulada vir a exaurir a própria ordem que se pleiteia seja concedida ao final. 2. Inexistência, ademais, de plausibilidade da alegação de ilegalidade do processo administrativo, porquanto constatada a prática da infração disciplinar e evidenciada a regularidade do procedimento apuratório, em respeito aos princípios do contraditório, da ampla defesa e da razoabilidade. 3. Discricionariedade da Administração na análise do conjunto probatório constante nos autos de processo disciplinar. Impossibilidade de controle judicial dos juízos de oportunidade.
4. Inexistência de perigo de ineficácia do provimento judicial buscado, caso ao fim seja concedida a ordem rogada no mandamus.

5. Manutenção da decisão que indeferiu o pedido de liminar.

6. Recurso a que se nega provimento. ${ }^{8}$

Destarte, resta evidente que para proceder à demissão de um servidor público estável, a Administração Pública, por meio das autoridades competentes, deverá observar todas as formalidades essenciais à aplicação da penalidade, sob pena de ser invalidado o seu ato e o servidor demitido reintegrado ao cargo sem prejuízo de seus vencimentos ao tempo em que teve afastado de suas funções ilegalmente.

\section{CONCLUSÃO}

Diante do exposto, pode-se afirmar que o processo administrativo disciplinar, desde que respeitado o devido processo legal, oportunizando defesa ao servidor acusado é o instrumento colocado à disposição da

\footnotetext{
${ }^{8}$ Agravo de Instrumento em Mandado de Segurança. Data do julgamento: 29/10/2015. Disponível em: <http://www5.tjmg.jus.br/jurisprudencia/pesquisaPalav rasEspelhoAcordao.do;jsessionid=B93261B2F61449A E6574411745987B3F.juri_node1?numeroRegistro=1\& totalLinhas $=1 \&$ palavras $=$ processo + administrativo + rein tegra\%E7\%E3o\&pesquisarPor=ementa\&pesquisaTesa uro $=$ true \&orderByData $=1 \&$ codigoOrgaoJulgador $=\&$ co digoCompostoRelator $=\&$ dataPublicacaoInicial $=\&$ data PublicacaoFinal=\&dataJulgamentoInicial=\&dataJulga mentoFinal $=\&$ siglaLegislativa $=\&$ referenciaLegislativa $=$ Clique+na+lupa + para + pesquisar+as + refer\%EAncias + cadastradas...\&numeroRefLegislativa $=\& a n o$ RefLegisla tiva $=\&$ legislacao $=\&$ norma $=\&$ desc Norma $=\&$ compleme nto_ $1=\&$ listaPesquisa $=\&$ descricaoTextosLegais $=\&$ obs ervacoes $=\&$ linhasPorPagina $=10 \&$ pesquisaPalavras $=\mathrm{Pe}$ squisar> Acesso em 22 de janeiro de 2016
} 
Administração para apurar eventuais faltas funcionais cometidas por servidores, podendo, ao final, desde que constatada a culpa do indiciado, aplicar penalidades que vai de uma simples advertência até a demissão, com consequente perda do cargo, ainda que se trate de servidor estável.

Se obedecido o rito procedimental e não havendo excesso de competência da comissão processante e autoridade julgadora, a pena é aplicada e anotada na ficha funcional do servidor. Não havendo respeito ao devido processos legal, o servidor poderá buscar a via judicial para que a penalidade aplicada de forma ilegítima seja anulada.

Trata-se, pois, de um instrumento que deve ser utilizado pela Administração de forma responsável e totalmente em conformidade com os ditames legais, para que desta forma, o serviço seja prestado de forma eficiente por pessoas idôneas pertencentes aos quadros da Administração.

\section{REFERÊNCIAS}

ALEXANDRINO, Marcelo; PAULO, Vicente. Direito Administrativo descomplicado. São Paulo: Impetus. 2007

ANDRADE, Flávia Cristina Moura de. Direito Administrativo. 6. ed., Niterói, RJ: Ímpetos, 2012.

BRASIL. Constituição da República Federativa do Brasil, 1988.

BRASIL. Lei Federal no 8.112, de 11 de dezembro de 1990.
BRASIL. Lei Federal no 9.784, de 29 de janeiro de 1999.

BRASIL. Supremo Tribunal Federal.

BRASIL. Tribunal de Justiça de Minas Gerais.

BRASIL. Tribunal de Justiça do Rio Grande do Norte.

DI PIETRO, Maria Sylvia Zanella. Direito

Constitucional. São Paulo: Atlas. 2006

FILHO, José dos Santos Carvalho. Manual de Direito Administrativo. 17. ed.. Rio de Janeiro: Lúmen Júris. 2007

MARINELA, Fernanda. Direito

Administrativo. 4. ed.. São Paulo: Impetus. 2010

MELLO, Celso Antônio Bandeira. Curso de Direito Administrativo. 17. ed. São Paulo: Malheiros. 2004

MEIRELLES, Hely Lopes. Direito administrativo brasileiro. São Paulo: Malheiros. 2009 